\title{
Efektivitas Pelaksanaan Restrukturisasi Kredit Sebagai Strategi Penurunan Kredit Bermasalah Selama Pandemic Covid-19 Pegadaian Kanwil Balikpapan
}

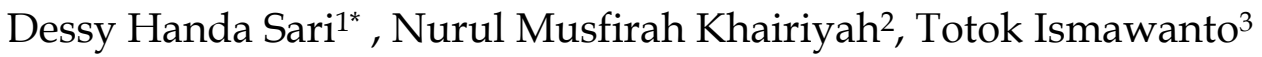 \\ ${ }_{1}$ Politeknik Negeri Balikpapan, Il Soekarno Hatta Km 8, Balikpapan, 76126, Indonesia \\ 2 Politeknik Negeri Balikpapan, Jl Soekarno Hatta Km 8, Balikpapan, 76126, Indonesia \\ ${ }^{3}$ Politeknik Negeri Balikpapan, Jl Soekarno Hatta Km 8, Balikpapan, 76126, Indonesia
}

\begin{tabular}{|c|c|}
\hline ARTICLE INFO & Abstract \\
\hline $\begin{array}{l}\text { Article History: } \\
\text { Accepted : } 2021 \\
\text { Fixed : } 2021 \\
\text { Approved: } 2021\end{array}$ & \multirow[b]{2}{*}{$\begin{array}{l}\text { The problem that is often faced by financial institutions is the problem of } \\
\text { non-performing loans (NPL). Likewise, experienced by Pegadaian Kanwil } \\
\text { Balikpapan, As a result of non-performing loans, it can increase the level of } \\
\text { NPL which will have an impact on the health of financial institutions if not } \\
\text { handled quickly and appropriately. So that financial institutions use credit } \\
\text { restructuring as a strategy to reduce non-performing loans. This research is } \\
\text { a field research (field research), the nature of descriptive qualitative } \\
\text { research, data collection using interview and documentation techniques. } \\
\text { The results of the study state that non-performing loans/bad loans can } \\
\text { occur in the first } 2 \text { products, namely pawn products, customers do not pay } \\
\text { as much as their obligations until the due date as agreed in the and Rahn } \\
\text { Proof, while in non-pawning products, customers do not pay their monthly } \\
\text { obligations according to the installment payment due date as agreed in the } \\
\text { micro product fiduciary credit agreement. Analysis of the Effectiveness of } \\
\text { the Implementation of Credit Restructuring as a Strategy for Reducing } \\
\text { Non-performing Loans at the Balikpapan Branch Pawnshop. Based on the } \\
\text { results of research conducted, it can be said that the implementation of } \\
\text { credit restructuring in reducing non-performing loans carried out by } \\
\text { Pegadaian has been carried out in a persuasive and familial manner to the } \\
\text { debtor. }\end{array}$} \\
\hline $\begin{array}{l}\text { Keywords: } \\
\text { Credit Restructuring; Non- } \\
\text { Performing Loans; Pawnshop of } \\
\text { Balikpapan Regional Office }\end{array}$ & \\
\hline & Abstraks \\
\hline $\begin{array}{l}\text { Kata Kunci: } \\
\text { Restrukturisasi Kredit; Non } \\
\text { Performing Loan; Pegadaian kanwil } \\
\text { Balikpapan }\end{array}$ & \multirow[b]{2}{*}{$\begin{array}{l}\text { Masalah yang sering dihadapi Lembaga keuangan yaitu kredit } \\
\text { bermasalah atau Non Performing Loan (NPL). Sama halnya dengan } \\
\text { masalah yang dialami oleh Pegadaian Kanwil Balikpapan, dimana } \\
\text { faktor yang menyebabkan terjadinya kredit bermasalah tersebut } \\
\text { diantaranya ketidaklayakan debitur, kesalahan penggunaan kredit } \\
\text { dalam mengelola usaha, tetapi untuk saat ini adalah karena adanya } \\
\text { pengaruh dari Pandemic Covid 19. Akibatnya, kredit bermasalah } \\
\text { tersebut dapat meningkatkan tingkat NPL yang akan berakibatpada } \\
\text { kesehatan lembaga keuangan apanila tidak ditangani dengan cepat } \\
\text { dan tepat. Sehingga demikian, Lembaga keuangan menggunakan } \\
\text { restrukturisasi kredit sebagai strategi penurunan kredit bermasalah. } \\
\text { Penelitian ini merupakan penelitian lapangan (field research), sifat } \\
\text { penelitian deskriptif kualitatif, pengumpulan data menggunakan } \\
\text { teknik wawancara dan dokumentasi. Hasil penelitian menyatakan } \\
\text { bahwa kredit bermasalah/ kredit macet bisa terjadi dalam } 2 \text { produk } \\
\text { yang pertama adalah produk gadai, nasabah tidak membayar } \\
\text { sebesar kewajibannya sampai dengan tanggal jatuh tempo seperti } \\
\text { yang telah diperjanjikan pada Surat Bukti Gadai dan Surat Bukti }\end{array}$} \\
\hline DOI: & \\
\hline
\end{tabular}




\begin{tabular}{|l|l|l|}
\hline & $\begin{array}{l}\text { Rahn, sedangkan pada produk non gadai, nasabah tidak membayar } \\
\text { kewajiban setiap bulannya sesuai dengan tanggal jatuh tempo bayar } \\
\text { angsuran seperti yang telah di perjanjikan dalam perjanjian kredit } \\
\text { fidusia produk mikro Analisis Efektivitas Pelaksanaan } \\
\text { Restruktursisai kredit Sebagai Strategi Penurunan Kredit Bermasalah } \\
\text { pada Pegadaian Cabang Balikpapan. Berdasarkan hasil penelitian } \\
\text { yang peneliti lakukan di Pegadaian Cabang Balikpapan, sehinga } \\
\text { dapat dikatakan bahwa pelaksanaan restrukturisasi kredit dalam } \\
\text { menurunkan kredit bermasalah yang dilakukan oleh Pegadaian } \\
\text { sudah dilakukan secara persuasive dan kekeluargaan terhadap } \\
\text { debitur. }\end{array}$ \\
\hline $\begin{array}{l}\text { Correspondence: } \\
\text { Name: Dessy Handa Sari } \\
\text { Email: dessy.handasari.poltekba.ac.id }\end{array}$ & $\begin{array}{l}\text { ISSN: 2355-9543 (Print) } \\
\text { ISSN: 2460-3775 (Online) }\end{array}$ \\
\hline
\end{tabular}

\section{PENDAHULUAN}

Kredit bermasalah (Ismail, 2013) adalah kredit yang telah disalurkan oleh suatu lembaga keuangan, dan debitur tidak dapat melakukan pembayaran atau angsuran sesuai dengan perjanjian yang telah ditandatangani oleh bank dan nasabah. Bank Indonesia (BI) menetapkan arah dan kebijakan agar setiap lembaga keuangan secara bertahap dapat menurunkan NPL sampai dengan tingkat tidak lebih dari $5 \%$.

Berikut terdapat beberapa permasalahan mengenai kredit bermasalah di Pegadaian Kanwil Balikpapan diantaranya : Pegadaian Kanwil Balikpapan hampir setiap tahunnya sering mengalami resiko kredit bermasalah, dalam setahun terdapat begitu banyak berkas debitur bermasalah yang dilakukan penyelamatan melalui restrukturisasi kredit oleh pihak Pegadaian Kanwil Balikpapan. Permasalahan ini timbul dari kredit bermasalah yang berkaitan dengan adanya pandemic covid 19 selama tahun 2020.

Berdasarakan hasil wawancara yang dilakukan di Pegadaian Kanwil Balikpapan, didapatkan data jumlah kredit bermasalah pada tahun 2017, 2018, 2019 dan 2020. Dilihat dari permasalahan yang ada maka dibutuhkan strategi yang dapat mengantisipasi kerugian yang diakibatkan kredit bermasalah, yakni salah satunya diantaranya dengan menggunakan strategi restrukturisasi sebagai upaya pengamanan sehingga tidak semakin parah dan mengakibatkan sulitnya penyelesaian kredit bermasalah. Restrukturisasi kredit adalah upaya yang dilakukan dalam perbaikan di lembaga keuangan dalam kegiatan perkreditan terhadap debitur yang mengalami kesulitan untuk memenuhi kewajibannya yang diatur dalam Peraturan Otoritas Jasa Keuangan No.11/POJK.03/2015 dan PBI Nomor 14/15/PBI/2012. Program restrukturisasi kredit akan memberikan pembayaran hutang dengan syarat yang lebih lunak atau lebih ringan dibandingkan dengan syarat sebelum proses restrukturisasi sehingga dapat memperbaiki posisi keuangan debitur. Dalam Surat Edaran Bank Indonesia (SEBI) Nomor 23/12/BPPP tanggal 28 Februari 1991, menjelaskan beberapa kebijakan dalam penyelamatan kredit macet, mulai dari rescheduling (penjadwalan kembali), reconditioning (persyaratan kembali), restructuring (penataan kembali).

\section{METODE}

Adapun jenis dari penelitian ini yaitu penelitian lapangan (field research) dimana kemampuan seseorang untuk menggunakan pengamatannya melalui hasil kerja panca indra mata serta dibantu dengan panca indera. Penelitian ini menggunakan sumber data yang terbagi menjadi dua macam, yaitu sumber data primer dan sumber data sekunder. 
Dalam penelitian ini menggunakan Analisis data dengan langkah-langkah sebagai berikut : yang Pertama, dimulai dari mengkaji data yang diperoleh dari beberapa sumber, dalam penelitian ini yaitu dari hasil wawancara dan dokumentasi. Kedua, mengadakan reduksi data dengan melakukan abstraksi yang merupakan usaha membuat rangkuman yang inti, tujuannya untuk memfokuskan pada masalah yang akan diteliti, dalam penelitian ini yaitu masalah mengenai efektivitas restrukturisasi sebagai strategi penurunan kredit bermasalah. Ketiga, menyusunnya dalam satuan-satuan yang kemudian dikategorisasikan pada langkah berikutnya yang ditetapkan sebagai fokus peneitian, dalam penelitian ini yaitu dikategorikan mengenai efektivitas, pelaksanaan restrukturisasi kredit, dan kredit bermasalah. Keempat, verifikasi atau mengadakan pemeriksaan keabsahan data, pada tahap ini peneliti mencocokkan data penelitian terkait kepentingan dan keabsahannya yang diperoleh dari setiap pertanyaan yang diajukan dengan jawaban yang didapatkan. Kelima, tahap penafsiran dalam mengolah hasil dan kesimpulan, dalam tahap ini peneliti akan menafsirkan isi dari penelitian yang kemudian hasil dari penafsiran tersebut akan diolah secara singkat dan jelas menjadi sebuah kesimpulan

\section{HASIL DAN PEMBAHASAN}

Pegadaian adalah sebuah BUMN sektor keuangan Indonesia yang bergerak pada tiga lini bisnis yaitu pembiayaan emas, dan aneka jasa. Menurut Undang-Undang Hukum Perdata pada pasal 1150, gadai adalah hak yang diperoleh seorang yang mempunyai piutang atas suatu barang bergerak. Barang bergerak tersebut diserahkan kepada orang yang berpiutang oleh seorang lain atas nama orang yang mempunyai utang. Seorang yang berutang tersebut memberikan kekuasaan kepada orang yang berutang untuk menggunakan barang bergerak yang telah diserahkan untuk melunasi utang apabila pihak yang berutang tidak dapat memenuhi kewajibannya pada saat jatuh tempo.

Efektifitas Pelaksanaan Restrukturisasi Kredit Sebagai Strategi Penurunan Kredit Bermasalah Pada Pegadaian Cabang Balikpapan. Cara untuk mengetahui efektivitas pelaksanaan restrukturisasi kredit sebagai strategi penurunan kredit bermasalah di Pegadaian Cabang Balikpapan, maka dari itu peneliti melakukan wawancara terhadap karyawan Pegadaian Cabang Balikpapan ber,aksud untuk menggali informasi mengenai penelitian. Berdasarkan hasil wawancara peneliti dengan bagian marketing dan kepala Departemen Manajemen Risiko Pegadaian Cabang Balikpapan, kredit bermasalah yang terjadi di Pegadaian Cabang Balikpapan disebabkan oleh beberapa faktor, diantaranya yang dijelaskan oleh RM Pegadaian Cabang Balikpapan:

"Kredit bermasalah/ kredit macet bisa terjadi dalam 2 produk yang pertama adalah produk gadai, nasabah tidak membayar sebesar kewajibannya sampai dengan tanggal jatuh tempo seperti yang telah diperjanjikan pada Surat Bukti Gadai (SBG) dan Surat Bukti Rahn (SBR), sedangkan pada produk non gadai, nasabah tidak membayar kewajiban setiapo bulannya sesuai dengan tanggal jatuh tempo bayar angsuran seperti yang telah di perjanjikan dalam perjanjian kredit fidusia produk mikro"

Tahun 2020 terjadi pandemic Covid 19 yang menyebabkan debitur banyak mengalami kendala yang tidak terduga seperti seorang karyawan, nasabah di phk (dipecat dari perusahaan tempat berkerja), serta musibah dan berbagai kejadian yang tidak disengaja juga menjadi penyebab debitur mengalami kendala dalam pembayaran angsuran yang mengakibatkan angsuran kredit menunggak sehingga menjadi kredit bermasalah. Adapun debitur yang mengalami kredit bermasalah kebanyakan adalah debitur yang mengambil kredit dengan angsuran bulanan, dikarenakan kemampuan debitur dalam membayar angsurannya ditentukan dan tergantung pada pendapatan perbulan, jika pada bulan tertentu mereka mengalami 
penurunan maka secara tidak langsung akan mengakibatkan terlambat membayar angsurannya. Penjelasan mengenai dampak kredit bermasalah yang dialami oleh Pegadaian Cabang Balikpapan dipaparkan oleh Kepala Departemen Manajemen Risiko Bapak Joko Suryanto, diantaranya "Kinerja Pegadaian Cabang Balikpapan menjadi kurang maksimal, karena menimbulkan banyaknya produk gadai yang mengalami gagal bayar, yang mengakibatkan tertundanya pendapatan bunga yang seharusnya menjadi profit/ keuntungan Pegadaian, yang akan berakibat pada menurunnya pendapatan Pegadaian secara total. Kemudian permasalah tersebut juga berakibat pada meningkatnya Non Performing Loan (NPL) yang dapat mempengaruhi kesehatan Pegadaian jika tidak dtangani secara cepat dan tepat." Sedangkan menurut RM Pegadaian Cabang Balikpapan “Dengan adanya kredit bermasalah maka: Tingkat NPL naik; Peluang memperoleh pendapatan tertunda; Modal idle menimbulkan COF naik; Penyaluran kredit oleh petugas terhampat, karena harus mengurusi kredit bermasalah ini; Pengurusan klain penjaminan kredit ke pihak Asuransi Penjamin." Dalam penanganan kredit bermasalah, Pegadaian Cabang Balikpapan menerapkan Langkah dalam penyelesaian kredit bermasalah yakni salah satunya dengan restrukturisasi kredit untuk menurunkan tingkat NPL atau kredit bermasalah yang terjadi. Berdasarkan hasil wawancara peneliti dengan Kepala Departemen Manajemen Risiko Bapak Joko Suryanto, penangannan kredit bermasalah untuk produk Gadai: "Setelah jatuh Tempo dan Sebelum dilakukan cut off kreditnya, Tindakan yang dilakukan pengadaian: Memberitahukan secara tertulis kepada nasabah yang disebut Surat Pemberitahuan Telah Jatuh Tempo dan Barang Jaminan segera di lelang, Memberitahukan secara cepat melalui media aplikasi: telephone, SMS dan WA, Pengumuman lelang di media masa seperti : Koran, radio dan televise. Hal ini dilakukan agar nasabah segera melakukan perpanjangan kreditnya secara ulang gadai, cicil pokok kreditnya, Top up pokoknya atau ditebus sebelum tanggal lelang" Sedangkan untuk Produk non Gadai: "Setelah nasabah menunggak pembayaran angsuran $3 x$, Tindakan yang dilakukan Pegadaian: Mengirimkan surat peringatan (somasi) ke 1, ke 2 dan ke 3 dengan interval waktu 7 hari dari somasi sebelumnya, dengan maksud agar nasabah melakukan pembayaran kewajiban, Jika dengan somasi ke 1 sd ke 3, nasabah tetap belum melakukan pembayaran kewajiban maka petugas Pegadaian akan melakukan penarikan fisik barang Jaminan yang masih dalam penguasaan nasabah untuk dijual secara lelang atau pun penjualan langsung kepada konsumen yang berminat."

$$
\text { Pegadaian Cabang Balikpapan }
$$

melaksanakan restrukturisasi pada tahun 2020 yang dilatarbelakangi karena adanya risiko pandemic covid 19 di Indonesia bahkan secara global. Di saat pandemic covid 19 tingkat NPL yang terjadi di Pegadaian cabang Balikpapan mengalami peningkatan yaitu dimana pada 31 Januari 2020 tingkat NPL di Pengadaian Cabang Balikpapan sebesar 1.86\% kemudian di 31 Juli 2020 mengalami penurunan NPL sebesar $0,18 \%$ yaitu menjadi $1,68 \%$ hal ini dikarenakan terjadinya pandemic covid 19 dan di Balikpapan sedang dilaksanakan Lockdown. Dan pada saat ini penurunan terjadi dikarenakan peningkatan kredit yang terjadi di Pegadaian Cabang Balikpapan. Selanjutnya pada Bulan desember NPL ditutup pada $1,12 \%$, hal ini dikarenakan telah dilakukan restrukturisasi sesuai dengan peraturan pemerintah. Dan pada bulan Januari 2021 terjadi peningkatan sebesar 0,40\% menjadi 1,52\%. Dan pada saat data ini di ambil tingkat NPL yang terjadi sebesar 3,52\%.

Pandemic covid 19 menyebabkan tingkat kredit bermasalah mengalami kenaikan karena terhambatnya atau terganggunya iklim berusaha pelaku ekonomi di Indonesia, khususnya kota Balikpapan, seperti dilakukan PSBB, PPKM dan pengetatan akibat diberlakukannya protocol kesehatan. Seperti yang dijelakan oleh Bapak Joko Suryanto yang mengatakan: "Pegadaian 
juga wajib mengikuti perintah Presiden RI untuk memberikan Relaksasi kepada nasabah yang usahanya atau penghasilannya terdampak oleh pandemic covid 19". "Kebijakan Restruturisasi bagi Nasabah Pegadaian yang terkena dampak wabah Corona Virus Disease (Covid 19), sesuai dengan perintah Presiden Republik Indonesia dalam pidatonya di Istana Negara Pada hari Selasa tanggan 24 maret 2020 mengumumkan Sembilan kebijakan untuk menyelematkan ekonimi dari dampak pandemic corona virus disease (Covid 19). Salah satu kebijakan yang disampaikan adalah "otoritas Jasa Keuangan (OJK) memberikan relaksasi kredit dibawah Rp 10 Miliar untuk Usaha Mikro Kecil dan Menengah (UMKM), Relaksasi tersebut berupa penurunan bunga dan penundaan cicilan selama setahun, baik dari Perbanakan dan Industri Keuangan Non Bank". Selain iti, penangguhan cicilan selama setahun berlaku bagi ojek, supir taksi dan nelayan yang memiliki cicilan kendaraan, serta meminta pihak Perbankan dan Keuangan Non Bank untuk tidak mengejar para debitur apalagi menggunakan jasa penagihan atau debt collector."

\section{Analisis Efektivitas Pelaksanaan}

Restruktursisai kredit Sebagai Strategi Penurunan Kredit Bermasalah pada Pegadaian Cabang Balikpapan. Berdasarkan hasil penelitian yang peneliti lakukan di Pegadaian Cabang Balikpapan, sehingga dapat dikatakan bahwa pelaksanaan restrukturisasi kredit dalam menurunkan kredit bermasalah yang dilakukan oleh Pegadaian sudah dilakukan secara persuasive dan kekeluargaan terhadap debitur. Dengan dilaksanakannya restrukturisasi kredit sebagai strategi penurunan kredit bermasalah sesuai standar dan kebijakan yang telah diterapkan oleh Pegadaian Cabang Balikpapan diharapkan dapat sesuai dengan tujuan dan target yang telah ditetapkan. Dalam penanganan kredit bermasalah, Pegadaian Cabang Balikpapan mengambil Langkah-langkah penyeleseian kredit bermasalah dengan restrukturisasi kredit untuk menurunkan tingkat NPL atau kredit bermasalah yang terjadi. Restrukturisasai kredit merupakan upaya perbaikan yang dilakukan bank dalam kegiatan perkreditan terhadap debitu yang mengalami kesulitan untuk memenuhi kewajibannya, restrukturisasi kredit dapat dilakukan dengan beberapa metode yaitu perpanjangan jangka waktu, penundaan pembayaran angsuran hingga 1 tahun, dan pembebasan denda untuk nasabah yang terkena dampak virus corona (covid 19).

Berdasarkan hasil wawancara peneliti dengan RM Pegadaian Cabang Balikpapan bahwa kriteria kredit nasabah yang bisa dilakukan restrukturisasi adalah "Produk Gadai : Secara otomatis sejak tanggal 01 April 2020 telah diberlakukan terhadap seluruh nasabah apapun kondisinya. Produk Non Gadai harus memenuhi syarat antara lain: Nasabah sedang mengalami kesulitan pembayaran kewajiban, dan mengajukan permohonan keringanan; Nasabah masih memiliki itikad baik untuk menyelesaikan kewajibannya; Masih mempunyai prospek usahanya; Nasabah sudah membayar angsuran kewajiban sekurang-kurangnya 3 (tiga) kali; Tidak sedang dalam proses perkara di Pengadian/ Kepolisian; Fisik barang Jaminan Kendaraan masih dalam penguasaan nasabah dan dalam kondisi baik; Kondisi keuangan usahanya/penghasilannya masih mampu membayar walau tidak sebesar angsuran yang telah diperjanjikan di awal transaksi akad, jika telah dilakukan restrukturisasi kreditnya; Telah dilakukan verifikasi ulang oleh Petugas Tim Mikro Pegadaian dengan kunjungan ke rumah/ tempat usaha nasabah dan dinyatakan layak diberikan restrukturisasi." Sedangkan kendala yang dihadapi dalam pelaksanaan restrukturisasi kredit bermasalah: "nasabah tidak memenuhi salah satu persyaratan tersebut diatas pada poin2b; selain itu belum memungkinkan dilakukan kunjungan untuk verifikasi nasabah karena adanya kebijakan Pemerintah Daerah dengan pemberlakuan PSBB, PPKM, dan pengetatan Protokol kesehatan di masa pandemic covid 19". Untuk 
menilai efektifitas pelaksanaan restrukturisasi kredit yang dilakukan Pegadaian Cabang Balikpapan untuk menurunkan kredit bermasalah atau tingkat NPL diperlukan adanya tolak ukur efektivitas, dimana pengukuran efektifitas dapat dilakukan dengan melihat hasil kerja yang dicapai oleh suatu organisasi, diukur melalui berhasil tidaknya organisasi mencapai tujuannya, apabila organisasi berhasil mencapai tujuannya maka dapat dikatakan efektif karena efektivitas hanya melihat apakah proses program atau kegiatan tersebut mencapai tujuan yang telah ditetapkan. Di Pegadaian ekseskusi Barang Jaminan produk Gadai paling efektif dalam menangani kredit macet dan bisa dilakukan setiap bulanm, karena Pegadaian diberi kewenangan untuk melakukan lelang sendiri. Sedangkan untuk eksekusi Barang Jaminan produk Non Gadai yang berbasis angsurah eksekusi Barang jaminan sebisa mungkin dihindari dan dijadikan sebagai upaya terakhir, karena memerlukan effort yang cukup besar sehinga tidak efektif. Berlandaskan teori dan olah data yang telah peneliti lakukan, dapat diketahui bahwa tolak ukur Pegadaian dalam menentukan efektivitas pelaksanaan restrukturisasi kredit sebagai strategi penurunan kredit bermasalah adalah dengan melihat pergerakan tingkat NPL yang terjadi, dalam hal ini selama tahun 2020 Pegadaqian cabang Balikpapan mengalami penurunan tingkat debitur bermasalah yaitu diakhir 31 Desember 2020 sebesar 1,12\% dibawah rata rata nasional. Selain itu, pelaksanaan restrukturisasi kredit yang dilakukan Pegadaian dikatakan efektif karena telah memenuhi beberapa penialaian atau indikatior yang menyatakan keefektifan pelaksanaan restrukturisasi kredit sebagai strategi penurunan kredit bermasalah, diantaranya: Kejelasan tujuan yang hendak dicapai, hal ini dibuktikan dengan tercapainya tujuan bank dalam menurunkan tingkat kredit bermasalah pada tahun 2020, Kejelasan strategi dalam mencapai tujuan, yaitu pihak bank telah menggunakan strategi restrukturisasi kredit dan dengan persuasive serta melalukan lelang terhadap barang jaminan kredit bermasalah, Proses analisi dan perumusan serta kebijakan yang baik, dilakukan dengann menerapkan prinsip $5 c$ dalam pelaksanaan restrukturisasi kredit untuk meninjau ulang kemampuan debitur. Perencanaan yang matang, hal ini juga telah dilakukan cukup baik oleh pihak Pegadaian sebelum melakukan penyelamatan kredit bermasalah kepada debitur, baik mengenai penyelesaiannya sampai pada akibat kredit bermasalah dimasa mendatang. Penyusunan program yang tepat, hal ini dilakukan dengan penjabaran program restrukturisasi kredit dengan berbagai opsi perpanjangan jangka waktu, penundaan pembayaran angsuran hingga 1 tahun, dan pembebasan denda untuk nasabah yang terkena dampak virus corona (covid 19).

Menurut (Hessel, 2005) Efektifitas mempunyai arti dimana suatu keadaan yang menunjukkan keberhasilan kerja yang ditetapkan untuk mengukur hasil yang dicapai sesuai dengan rencana dan tujuan, jadi semakin banyak rencana yang dapat dicapai, maka semakin efektif pula kegiatan tersebut, sehingga kata efektifitas dapat diartikan sebagai tingkat keberhasilan yang dapat dicapai dari suatu usaha. Penjelasan yang diperoleh dari wawancara peneliti dengan Kepala Departemen Manajemen Risiko Pegadaian Cabang Balikpapan sudah efektif, dimana dalam pelaksanaannya sudah sesuai dengan prosedur dan kebijakan yang telah ditetapkan oleh internal Pegadaian dan peraturan yang berlaku. Efektifitas tersebut dapat dibuktikan dengan semakin menurunnya presentase NPL dan jumlah debitur NPL di tahun 2020. Penurunan tersebut tidak lain disebabkan oleh efektifnya pelaksanaan restrukturisasi kredit yang dilakukan oleh pihak Pegadaian, Pegadaian sangat mengupayakan restrukturisasi kredit dengan melakukan monitoring atau pengawan terhadap debiturnya, yang kemudian melakukan evaluasi, analisis dan peninjauan kembali terhadap debiturnya bermasalah untuk mengetahui problematika 
usaha debitur yang mengalami tunggakan kredit, setelah hal tersebut diketahui dan diperoleh informasi tersebut sebagai dasar pihak Pegadaian dalam menentukan metode penyelamatan kredit debitur, salah satunya yaitu akan dilakukan restrukturisasi kredit. Selain itu, iktikad baik, transparasi debitur dan sikap kooperatif debitur menjadi penunjang pelaksanaan kredit menjadi efektif dalam menurunkan kredit bermasalah di Pegadaian Cabang Balikpapan. Sehingga dalam penelitaian ini dapat dikatakan bahwa, pihak Pegadaian telah melaksanakan penyelamatan kredit sesuai dengan (PERATURAN OJK NOMOR 11/POJK.03/2020, 2020) tentang stimulus perekonomian Nasional Sebagai kebijakan Countercyclical Dampak Penyebaran Corona virus Disease 2019, dengan kebijakan dari Pegadaian berupa, perpanjangan jangka waktu, penundaan pembayaran angsuran hingga satu tahun, dan pembebasan denda untuk nasabah yang terkena dampak virus corona (Covid19).

\section{KESIMPULAN DAN SARAN}

Pegadaian Cabang Balikpapan telah melakukan restrukturisasi kredit sesuai dengan peraturan perundang-undangan dan peraturan internal yang berlaku. Selama tahun 2020 Pegadaian cabang Balikpapan berhasil menurunkan NPL menjadi $1,12 \%$ di 31 Desember 2020 dan merupakan dibawah rata rata Nasional. Pegadaian cabang Balikpapan sesuai dengan peraturan (Peratur. OJK Nomor 48/POJK.03/2020, 2020) menetapkan kebijakan berupa: perpanjangan jangka waktu, penundaan pembayaran angsuran hingga 1 tahun, dan pembebasan denda untuk nasabah yang terkena dampak virus corona (covid19).

Pegadaian melakukan ekseskusi Barang Jaminan produk Gadai paling efektif dalam menangani kredit macet dan bisa dilakukan setiap bulan, karena Pegadaian diberi kewenangan untuk melakukan lelang sendiri. Sedangkan untuk eksekusi Barang Jaminan produk Non Gadai yang berbasis angsurah eksekusi barang jaminan sebisa mungkin dihindari dan dijadikan sebagai upaya terakhir, karena memerlukan effort yang cukup besar sehinga tidak efektif.

Pegadaian sangat mengusahakan restrukturisasi kredit dengan melakukan monitoring atau pengawan terhadap debiturnya, yang kemudian melakukan evaluasi, analisis dan peninjauan Kembali terhadap debiturnya bermasalah untuk mengetahui problematika usaha debitur yang mengalami tunggakan kredit, setelah hal tersebut diketahui dan diperoleh informasi tersebut sebagai dasar pihak Pegadaian dalam menentukan metode penyelamatan kredit debitur, salah satunya yaitu akan dilakukan restrukturisasi kredit. Selain itu, iktikad baik, transparasi debitur dan sika kooperatif debitur menjadi penunjang pelaksanaan kredit menjadi efektif dalam menurunkan kredit bermasalah di Pegadaian Cabang Balikpapan.

\section{DAFTAR PUSTAKA}

Hessel, N. s. (2005). Manajemen publik. Grasindo.

Ismail. (2013). Manajemen Perbankan Dari Teori Menuju Aplikasi. Kencana Prenadamedia Group.

Peraturan OJK Nomor 48/POJK.03/2020, 53 Peraturan OJK Nomor 48/POJK.03/2020 1689 (2020).

PERATURAN OJK NOMOR 11/POJK.03/2020， 11/POJK.03 (2020). https://emea.mitsubishielectric.com/ar/ products-solutions/factoryautomation/index.html 